\title{
The Implementation of The Pjbl Method Assisted by Padlet on Environmental Pollution Material on Student Science Literature
}

\author{
Yuni Arfiani $^{1^{*}, \text { Muriani Nur Hayati }^{2} \text {, Ikhza Khaerul Anwar }}{ }^{3}$ \\ ${ }^{1,2,3}$ Study Program of Science Education, FKIP, Universitas Pancasakti Tegal \\ Corresponding Author. Email: Yuniarfiani@gmail.com
}

Keywords:
PjB1, Padlet,
Science Literacy

\begin{abstract}
The study aimed to 1) determine the effect of learning using the PjBL model assisted by Padlet on environmental pollution material on student literacy, and 2) find out the student responses toward the learning using the PjBL model assisted by Padlet on environmental pollution material on students scientific literacy. The research used a quasi-experimental method with a Pretest-Posttest control group design. The sample selection techniques used Purpose Sampling, both Experiment and control class. Data collection techniques were questionnaires, documentation, and tests. Data analysis used the Independent Sample TTest and the coefficient of determination. The finding showed that the treatment of the research subject was the class. In the experimental class, the pretest score was 71.79 and the posttest score was 75.94. Meanwhile, in the control class, the pretest score was 60.27 and the posttest score was 66.53. The N-Gain value was 0.35 in the Experiment class and 0.31 in the control class, so it was in the medium category. In short, the implementation of the PjB1 model assisted by Padlet on environmental pollution material affects students' scientific literacy by $4.6 \%$.
\end{abstract}

\section{INTRODUCTION}

Education is a process of human needs, both formal and non-formal. Education can influence the students to adapt to the environment, then there will be a change in themselves that manifested into an attitude of interaction in the middle of the community. The low quality of education is influenced by students, educators, administrators, and the community (Stakeholders) (Iskandar, 2009). The Program for International Student Assessment (PISA) in 2018 showed that, since 2015, Indonesia has had a decline in reading science. In that case, the PISA 2018 would include a scenario that students required to read a collection of texts thematically that aims to complete the higher-level assignments. Then, the findings show that the scientific literacy ability of students in Indonesia is low. Learning activities focus on students is urgent that has a purpose to improve the quality of students, and the learning must able to meet a personal need, both community or the state (Munandar, 2004).

The low scientific literacy ability of students in Indonesia is influenced by a factor, either curriculum or teacher. The decline of students' scientific literacy skills is a problem in terms of the ability to understand science concepts and principles (Safitri 2015). The ability of a student's scientific literacy is very important to students, especially associating to modern society who likes a technological advance and a science.

Science subject requires students to lead to a critical awareness of how to maintain the natural environment and its surroundings. At the junior high school/Madrasah Tsanawiyah (SMP/MTS) level, science subjects are very important to be taught to students due to several reasons. First, Besides the knowledge reason, Science learning is also intended to foster critical thinking skills and abilities that are useful for solving a problem to enter the next level of education. Science is sometimes very less attractive to students, especially at the SMP/MTS level. Pasaribu and Simatupang (2020) stated that in the learning of science, especially in the environmental pollution material, stated by, students only know the concept of a theory without providing 
the solution when they know a problem in the surrounding environment.

According to Wahano, et al. (2017), Environmental pollution is the entry of living things, substances, energy, and other components into the environment by human activities. As a result, the quality drops to a certain level which causes damage to the environment, such as loss of function. In solving the environmental problems, a teacher should create a pleasant atmosphere and invited students to involve in the learning process, especially on the material of environmental pollution. Therefore, teachers also need to apply a learning model with an approach considering the aspects of science that are interconnected with students and develop an ability of students optimally (Muamar, 2017).

Then, the Project-Based Learning (PjBL) model is a good approach to the quality of the learning model. Siva, Moderawan, and Tika (2013) state, the Project-Based Learning $(\mathrm{PjBl})$ model is learning that refers to philosophy through real experience. In this case, project-based learning can improve students ' think critically and creatively, such as think fluency, flexibility, think originality and (Munandar, 2019). And, Project-Based Learning $(\mathrm{PjBl})$ is a learning model that actively involves students to design the learning objectives to produce a real product or project. In addition, using the Project-Based Learning ( $\mathrm{PjBl}$ ) model can also improve students' science process skills (Haryati, Supardi, and Miswati, 2013). In an online learning, the Project-Based Learning (PjBL) model requires a tool or media, for example, Padlet.

$\mathrm{PjBl}$ model assisted by Padlet may support the delivery of material to students. Also, it may have functioned as a place for discussion, group work, assignment delivery, and portfolio documentation. Then, students will be monitored in the term of development, skill and effort (Ghesta Lestari, et al., 2019).

The Padlet application is one of the internetbased learning media that functions as a place for various information, such as photos, text, links, and videos, and much other information which is commonly called a wall. Padlet is also an application that has a function to interact and communicate in collaborative learning (Dewit, Alias, \& Siraj, 2015). Ghesta Lestari, et al (2019) stated that the Padlet application had met international educational standards where the institution had surveyed and analyzed the feasibility of a learning media. The institution also shared its standardization in various fields of education. That is, by knowing the feasibility of media for students, for teachers, for leaders of teachers, for training, and for computer knowledge education. In short, the
Padlet application can be used as an alternative learning media today.

\section{METHOD}

This type of research was quasi-experimental, which had definition as research conducted by giving certain treatments to research subjects. There were two classes in the study, the experimental class, and the control class. The purpose of quasiexperiments is to control the external variables that affect the experiment (Susongko, 2016). The research site was Mts N 5 Tegal. The subject was students in class VII, in the 2020/2021 academic year. The research design was the Pretest-Posttest Control Design Group. Data collection techniques were questionnaires, documentation and tests, and non-tests, such as lesson plans, Student Video Project Sheets, questionnaires for student response, test questions of trial, Pretest, and Posttest. After it was conducted to validation of the instrument, it continued to Empirical Validity.

The item validity was calculated using the Product Moment Person Correlation. The construct validity test using the Product Moment Person Correlation was valid if $r_{x y}>r_{x y t}$, otherwise, if $r_{x y}>r_{x y t}$, then the item was invalid. And the calculation was used the following formula:

$$
r_{x y}=\frac{N \sum x y-\left(\sum x\right)\left(\sum y\right.}{\sqrt{(N) \sum x^{2}-\left(\sum x\right)^{2}\left(N \sum y^{2}-\left(\sum y\right)^{2}\right)}}
$$

Then, it continued to Reliability Test, aiming to determine the accuracy of the instrument. The instrument was reliable if has the appropriate results. This study used the Cronbach Alpha method. The formula was:

$$
\mathrm{r}_{\mathrm{ii}}=\frac{k}{k-1}\left(1-\frac{\sum S^{2}}{S^{2}}\right)
$$

(Susongko, 2016)

Then, testing the level of item difficulty indicated by the number percentage of participants that obtained the correct answer. The following formula was used to obtain the level of item difficulty in the form of a polytomous test:

$$
\mathrm{TK}=\frac{s}{N_{X} S_{\max }}
$$

(Susongko, 2016)

Determination power is the ability of a question to determine the high-ability students and low-ability students. The formula was:

$$
D P=\frac{\text { Mean } S_{A}+S_{B}}{\text { Skor Maksimal }}
$$

A normality test is used to determine the normal distribution of data. The study used SPSS version 21.0 for windows with the spharo Wilk test 
formula with a $95 \%$ confidence level and an error rate of $5 \%$ using the following formula:

$$
w=\frac{1}{\sum_{i=1}^{n}\left(x_{i}-x\right)} \sum_{i=1}^{k} a\left(X_{(n-i+1)}-X_{(i)}\right)
$$

Independent test Sample T-test is used to determine the effect of the Project-Based Learning model on students' scientific literacy. This study used the SPSS version 21.0 program for windows in analyzing the independent sample T-test. The statistical hypotheses of the study were:

Ho = Have no effect on the implementation of the PJBL model assisted by Padlet on environmental pollution material on students' scientific literacy.

$\mathrm{Ha}=$ have an effect in improving the implementation of the PJBL model assisted by Padlet on environmental pollution material on students' scientific literacy.

The calculation of the hypothesis was; first, the criteria of Ho were accepted if the significance level $>0.05$, then the $X$ variable has no effect on the $\mathrm{Y}$ variable. And, Ha rejected if the significance level $<0.05$, then the $\mathrm{X}$ variable has an influence on the $\mathrm{Y}$ variable.

The coefficient of determination is a rule to determine the influence of the independent variable on the dependent variable. If the coefficient of determination was 0 , means the independent variable has no influence at all $(0 \%)$ on the dependent variable. In contrast, if the coefficient of determination is 1 , means the dependent variable that showed of $100 \%$ was influenced by the independent variable. The coefficient of determination formula was:

$$
R^{2}=(R)^{2} \times 100 \%
$$

(Hake,R.R, 1999)

And, N-Gain Test was conducted to measure the improvement of each aspect of students' critical thinking skills with the formula of:

$$
\begin{gathered}
\mathrm{N} \text {-gain }=\frac{\text { Score of posttest }- \text { Score of Pretest }}{\text { Score of ideal }- \text { score of Pretest }} \\
\langle g\rangle=\frac{\left\langle S_{\text {Post }}\right\rangle-\left\langle S_{\text {Pre }}\right\rangle}{100 \%-\left\langle S_{\text {pre }}\right\rangle}
\end{gathered}
$$

\section{RESULT}

The data showed the results of the students' critical thinking skills before and after the learning and the increasing of students' learning outcomes, both in the experimental class and control class. The mean score of students' scientific literacy was seen from Pretest, PostTest, and N-Gain in both the experimental class and the control class. The data of the experiment class obtained a score of 71.79 (pretest), 75.94 (posttest), and 0.35 (N-Gain), which means that they were in the medium category. While the control class obtained a score of 60.27 (Pretest), 66.53 (PostTest), and 0.31 (N-Gain), which means that they were in the high category. This finding shows that inaccurate prior knowledge can be a barrier for students' development and accelerated (Astuti, 2011). According to Sudjana (2005), learning is a process marked by a change within a person. Change as a learning process is shown in various forms, such as knowledge, understanding, nature and behavior, the ability of receipt, and the individual, therefore learning is an active process.

The following diagram presented the mean score between the pretest and posttest, both the experimental class and the control class:

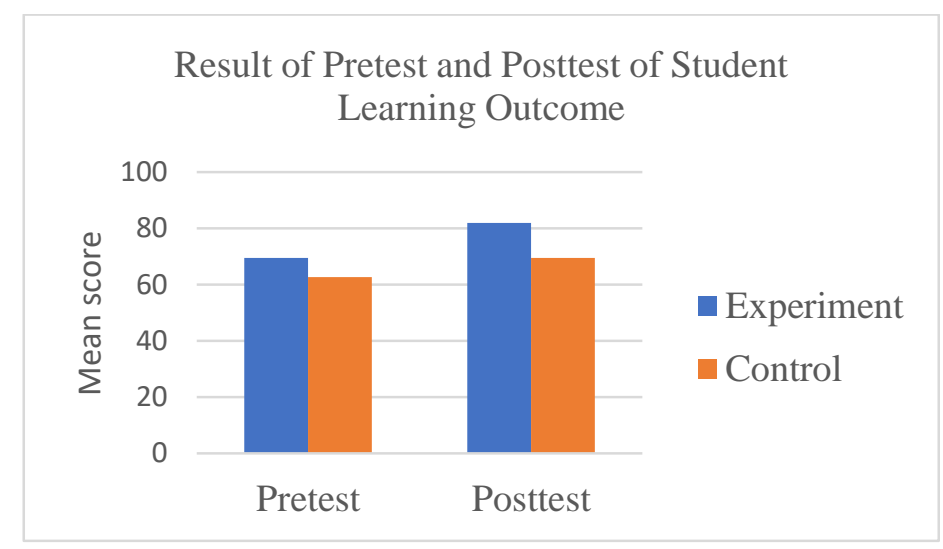

Diagram of Pretest and Posttest Results

Based on the diagram, there is a significant difference in learning outcomes between students in the experimental class and the control class that has increased the students' learning outcomes. The understanding ability of each student makes the difference in increased students' learning outcomes (Dewi Larasati, 2018). Another factor, the experimental class used the $\mathrm{PjBl}$ (Project Based Learning) model, while the control class used the conventional model. In line with Mesek and Yasmin 
(2011), the achievement of learning objectives is strongly influenced by the activities of students during learning activities. Student's learning outcomes are influenced by internal and external factors. Internal factors come from students themselves, such as learning readiness, attention, motivation, interest, perseverance, socioeconomic, psychological, and physical students. while, external factors come from external situations and conditions, such as teachers, learning atmosphere, facilities, resources, and school characteristics (Sudjana, 2005). Low learning motivation effects student learning outcomes (Sadirman, 2011). Moreover, learning models also play as an external factor as it gives opportunities for students to deliver ideas and solve problems in groups (Dewi and Prihandoro, 2017).

After found out that an online-PjBl (ProjectBased Learning) model affects students' critical thinking skills, then obtained the regression equation $\mathrm{Y}=80.102+0.391 \mathrm{X}$. The equation aimed to find out the equations of the $\mathrm{X}$ and $\mathrm{Y}$ variables. The equation is based on the simple linear regression formula, $\mathrm{Y}=\mathrm{a}+\mathrm{bX}$, where $\mathrm{Y}$ is a symbol of the dependent variable, a constant, b regression coefficient for the independent variable (X). The constant of 80,102 means that if the Project-Based Learning (X) model has a value of 0 , then scientific literacy $(\mathrm{Y})$ has a negative value of 80,102 . The variable regression coefficient is 0.391 , which means that if the $\mathrm{PjBl}$ (Project-Based
Learning) model increases by 1 , then critical thinking skills (Y) will increase by 0.391 .

The coefficient is positive, which means that there is a positive relationship between the ProjectBased Learning model variables (X) and the scientific literacy variable (Y). The higher the Project-Based Leaning ( $\mathrm{PjBL}$ ) model, the higher students' scientific literacy. Thus, it concluded that the PjBL (Project-Based Learning) model influences students' scientific literacy. Furthermore, a coefficient of determination test was conducted to find out the influence of the $\mathrm{X}$ variable on the $\mathrm{Y}$ variable. The calculation of the coefficient of determination obtained a score of $4.6 \%$. The score means that there is an influence of PjBL (ProjectBased Learning) on students' scientific literacy by $4.6 \%$, and the rest is influenced by other factors. Research conducted by Yesildere and Turnuklu (2006) in Satrika (2013) concluded that PjBL (Project-Based Learning) learning can lead a person to practice and understand complex thinking, and know-how to integrate it into skills that are often associated with real-life, able to use searching as a source, think critically and have good problemsolving skills could complete their project.

A questionnaire was used to find out the student's response whether the learning model is accepted or not. The results of the questionnaire completed by students, response to the use PjBL (Project-Based Learning) model assisted by Padlet, it presented in the diagram:

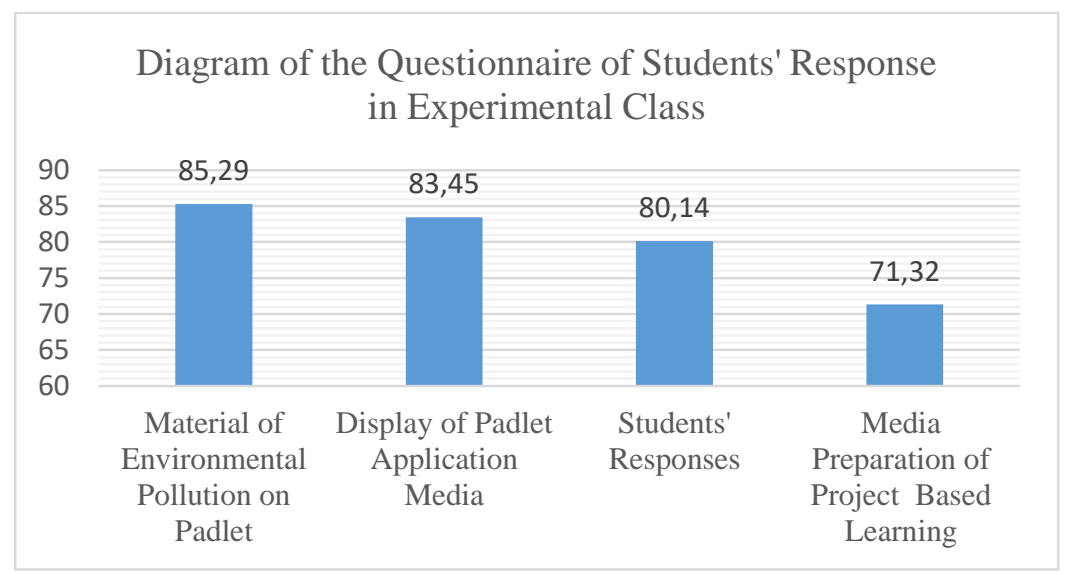

Diagram of the questionnaire of students' response for each indicator

Based on the diagram, the material of environmental pollution on Padlet application obtained a score of $85.29 \%$. The score was in an excellent category because students may like the material. The display aspect obtained a score of $83.45 \%$ with excellent category because the display may stimulate students to learn, and be happy while learning using the Padlet application. The student responses obtained a score of $80.14 \%$ with a good category because the Padlet application has attracted students in science learning. And, the aspect of preparation the project-based learning media obtained a score of $71.32 \%$ with a good category because students are motivated and foster a sense of students' enthusiasm and happiness.

Online learning teaches students independence because it can foster learning motivation. Motivation is the factor, both intrinsic (within students) and extrinsic (the surrounding environment) such as friends and teachers. External factors, generally hold a larger portion because of a friendship at school and the difficulties can turn into 
student learning motivation. The students will encourage to be better through discussion time, both with friends and teachers (Sari, 2015).

Project-Based Learning affects learning activities because students get used to being independent in learning as well as making projects that must be completed without face-to-face meetings with the teacher, students are more active to online learning, online learning is not limited by space and time, flexible learning activities and students are smart in finding information related to environmental pollution learning materials. By creating a login account on the Padlet can make variety in learning, ease students to understand the concepts, and motivate students to be more active in learning (Khasanah, 2018). And, the Project-Based Learning model is effective in terms of learning achievement, self-confidence, and critical thinking skills (Ilmawan, 2015).

In contrast to a positive impact, Project Based Learning also has a negative impact on online learning, such students sometimes still have difficulties with the project-based learning model, while the students in learning should be more guided and need time to change students into new learning models. Other negative impacts were inefficient learning time, network issues, and limited communication between students and teachers. These factors become a barrier to the learning process. Then, It needs solutions to solve the problems, such as students must be smarter in finding information or references to support broad knowledge, and must use technology as well as possible.

\section{CONCLUSION}

Based on the research that has been carried out at the MTs N 5 Tegal, concluded that:

1. Implementation of the PjBL model assisted by Padlet on environmental pollution material affects students' scientific literacy and Learning using the PjBL model assisted by Padlet affect students' scientific literacy by $4.6 \%$.

2. The students' response to the implementation of the PjBL learning model assisted by Padlet on environmental pollution material on students' scientific literacy was good.

The article suggests:

1. The implementation of learning with the PjBL model needs further development, especially when other materials have similar problems.

2. The learning planning with the PjBL model must be well-prepared, such as consider the time allocation, the condition of the students, and the level of the material difficulty.
3. The learning with the PjBL model is better carried out in a face-to-face meeting, and online learning is only used for the delivery of material.

4. The results of the study may use as reference and information in selecting effective and efficient teaching methods.

For further researchers, it is recommended to consider the barrier in using the PjBL learning model to find solutions that aim the learning wellrun.

\section{REFERENCES}

Aderson, T. (2008). The Theory And Practive Of Online Learning. Canada: Athabasca Universty Press.

Agency S. Thiagarajan, Sivasailam; And Others Instructional Development for Training Teachers of Exceptional Children: A Sourcebook. Indiana Univ., Bloomington. Center for Innovation in. (Mc).

Ainurrahman. (2011). Belajar dan pembelajaran. Bandung: Alfabeta.

Aizikovitsh-udi, E., \& Cheng, D. (2015). Developing Critical Thingking Skill from Dispositions to Abilities : Mathematics Education from Early Childhood to High, (March), 6(2), 455-462.

Arahim, Zaipudin. (2009). Ilmu Pengetahuan Alam : untuk SMP. MTs Kelas VII. Jakarta : Departemen Pendidikan Nasional.

Arifin, (2013). Evaluasi Pembelajaran Prinsip Tekhnik Prosedur. Bandung Remaja Rosdaka.

Arikunto, S. (2010). Prosedur Penelitian Suatu Pendekatan Praktik. Jakarta: Rineka Cipta.

Arikunto, Suharsimi. (2006). Prosedur Penelitian suatu pendekatan praktik. Jakarta: cipta.

Astuti, R. K. (2016). Model Pembelajaran Berbasis Masalah Untuk Meningkatkan Kreativitas Siswa Dalam Membuat Proyek Sains. PSEJ (Pancasakti Science Education Journal), 1(1), 50-59.

Astuti, T. (2011). Pembelajaran [online], tentang membangun pengetahuan awal atau apersepsi dalam kegiatan pembelajaran URL. http:// www. Poojetz Wordspress. Comanalisis.

Asyhari A. Profil Peningkatan Kemampuan Literasi Sains Siswa Melalui Pembelajaran Saintifik. J Ilm Pendidik Fis Al-Biruni. 2015;4(2):179. doi:10.24042/jpifalbiruni v4i2.91

Bell, S. (2010). Project-Based learning for the $21^{\text {st }}$ century: Skills for the future. The Clearning house, 83(2), 39-43

Cahyani NM, Indriyanto E, Masripah S. Uji Validitas dan Reabilitas Terhadap 
Implementasi Aplikasi Penjualan dan Pembelian. 2016;1(1):21-34.

Cahyani, N. M., Indriyanto, E., \& MAssripah, S. (2016). Uji Validitas dan Reliabilitas Terhadap Implementasi Aplikasi perjualan dan Pembelian. 1 (1), 21-34.

Deni AR, Sunway B. Using Padlet for Project-based Learning in Documentary Filmmaking. 2019;(5):0-5.

Dewitt D, Alias N, Siraj S. Collaborative learning: Interactive debates using Padlet in a higher education institution. Turkish Online J Educ Technol. 2015;2015:88-95.

Diana S, Rachmatulloh A, Rahmawati ES. Profil Kemampuan Literasi Sains Siswa SMA Berdasarkan Instrumen Scientific Literacy Assesments ( SLA ) High School Students, Scientific Literacy Profile Based on Scientific Literacy Assessments ( SLA ) Instruments. Published online 2015:285-291.

Framework A. PISA 2018 Assessment and Analytical Framework.; 2018.

Grade S, In V, Lesson S, Yogyakarta AT, Junior C. Profil aspek sikap literasi sains siswa smp kelas viii pada pembelajaran ipa di smpn kota yogyakarta ditinjau dari tingkat kefavoritan sekolah. :46-52.

Hake, R. R. (1999). Analyzing Change/ Gain Score. American Educational Research Methodology.

Hake, Richard R. (1999). Analiyzing Change/Gain Score. (Online). Diakses dari physics.indiana.edu/ sdi/AnalyzingChangeGain.pdf.

Haryanti, N., Widodo, A. T., \& Arfiani Y. (2019). Penerapan Model Discovery Learning pada Materi Pernapasan Global untuk Meningkatkan Keterampilan Berpikir Kritis Peserta Didik. Jurnal Edukasi Matematika dan Sains, 7(2), 55-64.

Hasibuan R. Analisis Dampak Limbah/Sampah Rumah Tangga Terhadap Pencemaran Lingkungan Hidup. Ilmiah. 2016;04(01):4252.

Hayati, W. I., Utaya. S., \& Astina, I. K. 2016. Efektivitas student worksheet berbasis project based learning dalam menumbuhkan kemampuan berfikir kritis siswa pada materi pelajaran geografi. Jurnal Pendidikan, 1(3), 468-474.

Hayati. M. N. (2016). Penggunaan Discrepant Events Dengan Pendekatan Poe Terhadap Hasil Belajar Kelarutan Dan Hasil Kali Kelarutan Siswa. PSEJ (Pancasakti Science Education Journal). 1(1).

Hayati. M. N., Supardi, K. I \& Miswadi, S. S. 2013. Pengembangan Pembelajaran IPA SMK dengan model konstektual berbasis proyek.
Inovative Journal of Curriculum and Education Technology. 2(1).

Ibrahim Z, Shing NK, Alias N, Dewitt D. Pembangunan Modul Pedagogi Pembelajaran Berasaskan Padlet Untuk Pelajar Pekak Di Ipt. Um Res Repos. Published online 2013:160-172. http://eprints.um.edu.my/id/eprint/13156

Latip A, Permanasari A. Pengembangan Multimedia Pembelajaran Berbasis Literasi Sains Untuk Siswa Smp Pada Tema Teknologi. Edusains. 2016;7(2):160-171. doi:10.15408/es.v7i2.1761

Lestari G, Mahbubah A, Masykuri MF. Pembelajaran Bahasa Arab Digital dengan Menggunakan Media Padlet di Madrasah Aliyah Billingual Batu. Proceeding Int Conf Islam Educ. 2019;4(1):238-244.

Mahasiswa S, Ipa J, Universitas $F$, et al. KEMAMPUAN LITERASI SAINS SISWA SMP PADA MATERI SUHU DAN PERUBAHANNYA Kirana Widya Hariapsari Dyah Astriani Suliyanah Abstrak. Published online 2010:1-5.

Mardapi, Djemari. (2008). Teknik penyusunan instrument tes dan nontes. Jakarta: Alfabeta.

Mawardini A, Permanasari A, Sanjaya Y. PROFIL LITERASI SAINS SISWA SMP PADA PEMBELAJARAN IPA TERPADU TEMA PENCEMARAN LINGKUNGAN SNF2015-IV-49 SNF2015-IV-50. 2015;IV(1996):49-56.

Muamar MR, Rahmawati, Irnawati. Pengaruh Penerapan Model Pembelajaran Project Based Learning (Pjbl) Yang Dipadu Metode Gallery Walk Terhadap Hasil Belajar Siswa Pada Konsep Pencemaran Lingkungan Kelas $\mathrm{X}$ Ipa SMA Negeri 1 Bireuen. Jesbio. 2017;6(1):17-23.

Muhson, Ali. (2010). Pengembangan Media Pembelajaran Berbasis Teknologi Informasi. Jurnal Pendidikan Akuntansi Indonesia, VII (2), 1-10.

Nasution R. Analisis Kemampuan Literasi Lingkungan Siswa SMA Kelas X di Samboja dalam Pembelajaran Biologi. 2016;13(1):352-358.

Ntobuo NE, Arbie A, Amali LN. Jurnal Pendidikan IPA Indonesia BASED ON GORONTALO CULTURE. 2018;7(2):246-251. doi:10.15294/jpii.v7i2.14344

OECD. (2018). PISA 2017 results (Volume1): Exellence and equty in education. PISA 2012 Fortschritte Und Herausforderungen in Deutschland.; 2012.

Pop B, Media UP, Sd AT, Pepe M. PENINGKATAN SIKAP PEDULI LINGKUNGAN MENGGUNAKAN 
MEDIA POP UP BERBASIS KARAKTER

PADA SISWA KELAS IA SD MUHAMMADIYAH. Published online 2018.

Prajitno SB. Pengetahuan, metode ilmiah, dan teori. J Penelit Publik. Published online 2008:1-29.

RINA PUTRI UTAMI RMPUF. Pengaruh Model Pembelajaran Project Based Learning Berbantu Instagram Terhadap Kemampuan Berpikir Kreatif Siswa Kelas X Sma Negeri 8 Surakarta. Bio-Pedagogi. 2015;4(1):47-52.

Sains DP. INTEGRASI LITERASI SAINS PESERTA DIDIK DALAM PEMBELAJARAN SAINS Risya Pramana Situmorang. : 49-5

Sains L. KELAYAKAN PERANGKAT PEMBELAJARAN BERDASARKAN MASALAH UNTUK MENINGKATKAN KEMAMPUAN LITERASI SAINS SISWA SMP Tsalis istighfarin Prihantya (1) , Mitarlis (2) , An Nuril Maulida (3) 1). 1974;(1):1-7.

Siwa, I.B., Muderawan, I.W., \& Tika, I.N (2013). Pengaruh Pembelajaran Berbasis Proyek dalam Pembelajaran Kimia terhadap Keterampilan Proses Sains ditinjau dari gaya kognitif siswa. E-Journal Program Pasca Sarjana Univeritas Pendidikan Ganesha. Vol.3 : 1-15

Subekti AS, Kurniawati LA. Pelatihan Mendesain Pembelajaran Daring Menarik Selama Pandemi Covid-19 dengan Teknologi Pembelajaran Sederhana. Din J Pengabdi Kpd Masy. 2020;4(4):588-595. doi:10.31849/dinamisia.v4i4.4679

Sudjana (2005). Penilaian Hasil Proses Pelajar Mengajar. Bandung: PT. Remaja Rosdakarya.

Sugiyono. (2010. Metode Penelitian Kuantitatif, Kualitatif, Dan $R$ \& D. Bandung: CV. Alfabeta.
Sugiyono. (2011). Metode Penelitian Kuantitatif , Kuantitatif dan R \& D. Bandung: Alfabeda CV.

Sugiyono. (2013). Statistik untuk penelitian. Bandung: CV. Alfabeta.

Sugiyono. (2015). Metode Penelitian Pendidikan (Pendekatan Kuantitaif, Kualitatif, dan $R \&$ D). Jakarta: Rhineka Cipta.

Sugiyono. (2016). Metode Penelitian Pendidikan. Bandung: Alfabeta.

Susongko, Purwo. (2016) Pengantar Metode Penelitian Pendidikan. Tegal: Universitas Pancasakti Tegal

Thomas, J. W. (2000). A review ff Research on Project-Based Learning

Wahano, D. (2017). Buku Guru Ilmu Pengetahuan Alam SMP/MTs Kelas VII. Jakarta: Kementrian Pendidikan dan kebudayaan.

Wahyu E, Fathurohman A, Markos S. Analisis Buku Siswa Mata Pelajaran IPA Kelas VIII SMP/MTs Berdasarkan Kategori Literasi Sains. $J$ Inov dan Pembelajaran Fis. 2016;3(2):14-24.

Wan Jusoh WNH, Abd Ghani R, Mohd Noor NA, Awang A, Sulaiman NH. Persepsi Pelajar Terhadap Penggunaan Video Dan Padlet (Pvdp) Dalam Pengajaran Dan Pembelajaran Subjek Pemikiran Dan Tamadun Islam. $e$ Academia J. 2019;8(2):1-7. doi:10.24191/eaj.v9i2.7378

Yusup F, Studi P, Biologi T, Islam U, Antasari N. UJI VALIDITAS DAN RELIABILITAS. 2018;7(1):17-23.Pembelajaran D, Siswa M, Dasar S, Saintifik ML. Desain Pembelajaran untuk Membimbing Siswa Sekolah Dasar dalam Memperoleh Literasi Saintifik. (April 2020).

Zhasda J, Sumarmin R. Analysis of Biological Science Literacy a Program for International Student Assessment ( PISA ) Class IX Junior High School Students at Solok Town. Int $J$ Progress Sci Technol. 2018;6(2):402-410. 